\title{
Collembola communities and soil conditions in forest plantations established in an intensively managed agricultural area
}

\author{
István Harta $^{1}$ - Barbara Simon ${ }^{1} \cdot$ Szergej Vinogradov $^{2}$. \\ Dániel Winkler ${ }^{3}$
}

Received: 15 March 2020 / Accepted: 23 June 2020 / Published online: 29 October 2020

(C) The Author(s) 2020

\begin{abstract}
The challenges of a changing climate have directed greater attention to afforestation, but the effects of afforestation on soil fertility and soil biota have not been fully clarified. To explore changes in the soil conditions in two 20-year-old forest plantations established in formerly intensively fertilized plots of agricultural land, we focused on the current developmental state of the sites that received the most fertilizer and evaluated soil properties and Collembola (springtails) communities. Sessile oak (Quercus petraea) and black locust (Robinia pseudoacacia) that had been planted in the afforestation sites were assessed for differences between plantations of native and invasive species. Five adjacent reference associations, including forests and open habitats, were also analyzed and compared. Results showed that the soils in the two afforested sites were similar in their properties and Collembola communities to those of the control cultivated forests, but differed from each other
\end{abstract}

Project funding: This work was supported financially by the project (EFOP-3.6.1-16-2016-00,018).

The online version is available at http://www.springerlink.com

Corresponding editor: Zhu Hong

Electronic supplementary material The online version of this article (https://doi.org/10.1007/s11676-020-01238-z) contains supplementary material, which is available to authorized users.

Dániel Winkler

winkler.daniel@uni-sopron.hu

1 Institute of Environmental Science, Szent István University, Gödöllő, Hungary

2 Institute of Methodology, Szent István University, Gödöllő, Hungary

3 Institute of Wildlife Management and Vertebrate Zoology, University of Sopron, Sopron, Hungary in $\mathrm{pH}$, calcium, phosphorus, and ammonium content. The available potassium and phosphorus contents in the soil of the sessile oak plantation were still high, while the soil organic matter content was adequate $(\mathrm{SOM}>2.0 \%)$ in both plantations. Species richness of Collembola ranged from 18 in the cultivated arable land to 43 in the relict forest. Only a few species typical for forests (e.g., Neanura muscorum, Isotomiella minor, Entomobrya muscorum) were detected in the young plantations, while species characteristic of open habitats (e.g., Protaphorura campata, Lepidocyrtus cyaneus) occurred as well. Although more individuals and species of Collembola were present in the soil of young plantations than in arable fields, their community diversities were significantly lower compared to the control forest stands. Collembola community diversity differed significantly also between the two plantation types (with native and non-native tree species). Mean abundance in the afforested sites was about 2.5 times higher than in the cultivated arable land, yet far lower than the mean abundance in the control forests.

Keywords Afforestation $\cdot$ Diversity $\cdot$ Fertilizers $\cdot$ Soil fauna $\cdot$ Soil properties $\cdot$ Springtails

\section{Introduction}

The most optimistic scenarios limit the global mean temperature increase to $1.5{ }^{\circ} \mathrm{C}$ relative to the pre-industrial level until the end of the twenty-first century, but only if the increase in atmospheric $\mathrm{CO}_{2}$ concentrations can be efficiently moderated (Rogelj et al. 2012, 2018). Land-use strategies must be thoroughly reconsidered to meet this goal. Forests continue to play a crucial role in the global carbon cycle (Bouwman and Leemans 1995; Lal 2004; Bonan 2008; Luyssaert et al. 2008; Pan et al. 2011; Law et al. 2018). 
Consequently, afforestation can make an important contribution to mitigate the effects of changing climate (Canadell and Raupach 2008; Mackey et al. 2013; Lawson and Michler 2014) and provide corridors within forest biomes, increase biodiversity, protect against soil erosion, regulate the hydrologic cycle, mitigate the effect of radiation and contribute to carbon, oxygen and nutrient cycling (Lindenmayer and Hobbs 2004; Farley et al. 2005; Arneth et al. 2010; Huang et al. 2010; Pawson et al. 2013; Peng et al. 2014; Paul et al. 2016; Torralba et al. 2016). The environmental benefits of afforestation are structural and functional, which depend on spatial design and maturity (Cunningham et al. 2015). While forests in many regions have been cleared and converted to agricultural uses (Gibbs et al. 2010; Laurance et al. 2014), abandoned or low-quality agricultural lands are more.

Arable land comprises $46.58 \%$ of Hungary's total area (KSH 2019). Agricultural activities have led to large-scale habitat conversions during the past century (Demeny and Centeri 2008; Munteanu et al. 2014; Konkoly-Gyúró and Balázs 2016). With the increase in cultivated areas, the area of forests and grasslands decreased significantly in Hungary. At present, more than half of the country is under agricultural cultivation. In the nineteenth century, grasslands in Hungary covered $30 \%$ of the area; the proportion now is only $8.5 \%$ (KSH 2019). Concerning forests, the proportion of forested areas in Hungary was only $11.8 \%$ after the First World War, although an estimated $85.5 \%$ of the country's current area should be naturally forested (Bartha 2000). These marked changes in the vegetation cover have led to habitat loss, fragmentation, and a complex set of biotic responses in the soil environment including significant loss of biodiversity (Poschlod et al. 2005; Heiniger et al. 2014). Nevertheless, over the past few decades, a considerable proportion of agricultural land in Europe has been converted into different land-use types such as grasslands or forests (Jongman 2002; Cunningham et al. 2015). A subsequent national afforestation program has increased forest cover in Hungary to $21 \%$, and the forest cover continues to increase. In many cases, however, afforestation has occurred with non-native species including black locust (Robinia pseudoacacia), which occupies one-fourth of the forested area in Hungary today (KSH 2019). Afforestation of abandoned or low-quality agricultural land has increased worldwide during the last two decades; thus, the ability to predict the long-term effect on soil property and biota following land-use change has become essential.

Afforestation can induce alterations in soil carbon content and pH (e.g., Paul et al. 2002; Vesterdal et al. 2002; Chen et al. 2008; Berthrong et al. 2009; Varamesh et al. 2014; Cunningham et al. 2015; Gao et al. 2018) and greatly affect the redistribution of soil macronutrients into biomass, nutrient cycling and stocks in soils (Farley and Kelly 2004; Shaifullah et al. 2009; Deng et al. 2017). Since soil biota are essential for soil processes and functions, they are widely used as bioindicators to monitor soil conditions after land-use changes (e.g., Kladivko 2001; Sousa et al. 2006; Vanbergen et al. 2007; Zhao et al. 2013; Menta et al. 2018). Characteristic communities of soil biota can call attention to properties of their natural environment that might be difficult to quantify as a measure of physical or chemical factors or vegetation type (Hopkin 1997). Springtails (Collembola) are among the best indicators within the soil mesofauna. They provide an important contribution in the mineralization of organic matter (Bardgett and Chan 1999; Kaneda and Kaneko 2008), thus helping plants absorb nutrients. Quick alterations in their community characteristics due to any type of soil degradation or changes in land-use make them suitable as test organisms as well (Giller et al. 1997; Zeppelini et al. 2009; Paul et al. 2011). However, responses after afforestation have not been completely ascertained. According to the heterogeneity theory, the diversity of animal communities is driven by habitat heterogeneity (Tews et al. 2003). We hypothesized that afforestation of highly degraded land provides higher heterogeneity over time, which is also reflected in Collembola diversity. Mosaics of surrounding habitats and corridors also play crucial role in colonization of newly afforested sites as source of fauna and dispersal routes (Sousa et al. 2004). This study presents the results of soil analyses and investigations of Collembola communities in two former longterm fertilization experimental sites afforested with native sessile oak (Quercus petraea) and non-native black locust, with adjacent characteristic habitats used as controls. Cultivated arable field was surveyed to get an idea of the initial community conditions, while the grassland formed on abandoned arable land represents the first phase of succession. Forests of both tree species that were managed for a long time, and a relict association were also included in the studies to obtain a more accurate comparative picture of the soil biological status of the studied plantations.

The main objectives were to (1) assess the soil conditions of the experimental sites 20 years after afforestation by comparing them to the control habitats; (2) evaluate the Collembola community response to the conversion of arable land to different types of forest plantation; (3) explore whether Collembola communities to some extent indicate traces of previous landuse; (4) specify the soil variables that are driving and determining Collembola communities after the conversion to forest has been made; and (5) detect the changes in community composition and biodiversity pattern along this habitat gradient.

\section{Materials and methods}

\section{Study area}

The study area is located in the Gödöllő Hills near Budapest in central Hungary (Fig. 1). The slightly sloping land 
stands between the flat area of the Great Hungarian Plain and the mountain range of northern Hungary. An approximately equal amount of intensive agricultural lands and cultivated forests characterize the landscape. The most commonly grown crops are grains, while the forests consist of native oak-dominated associations, as well as planted forests consisting of invasive species dominated by black locust. The natural vegetation also contains open and closed grasslands. Climatic conditions are moderately cold, moderately dry continental, with average yearly mean temperatures of 9.5-9.7 ${ }^{\circ} \mathrm{C}$. The minimum temperature is $-16^{\circ} \mathrm{C}$ and the maximum is $33{ }^{\circ} \mathrm{C}$. Annual hours of sunlight amounts to $1950 \mathrm{~h}$ while annual precipitation is $540-580 \mathrm{~mm}$. It is a rather dry area, and the available groundwater volume is low (Dövényi 2010).

The two examined 20-year-old plantations had been used for long-term fertilization experiments before the afforestation with sessile oak (OP), a common native species, and black locust (LP), a fast-growing, non-native species. The average 60-90 cm-thick soil of the study area was formed on bedrock sand mixed with loess from the Tertiary. The topsoil is shallow with an average $35-\mathrm{cm}$-thick humus layer. Carbonate appears at an average depth of $60 \mathrm{~cm}$, while the groundwater is below $4 \mathrm{~m}$. This soil can be classified as Luvic Endocalcic Phaeozem (Loamic, Aric) (IUSS Working Group WRB 2014). Originally, the upper $20 \mathrm{~cm}$ had a sandy soil texture that was slightly acidic $\mathrm{pH}\left(\mathrm{pH}_{\mathrm{KCl}} 5.0\right)$, had low SOM content (1.3-1.5\%), low available phosphorus $\left(p=15 \mathrm{mg} \mathrm{kg}^{-1}\right)$ and moderate potassium $\left(K=107 \mathrm{mg} \mathrm{kg}^{-1}\right)$ content and weak water-holding capacity. Until the afforestation, soil $\mathrm{NO}_{3}^{-}, p$ and $K$ was abundant as a consequence of NPK fertilization, while the $\mathrm{Ca}$ and $\mathrm{Mg}$ concentration as well as organic matter content and $\mathrm{pH}$ were low (Füleky and Debreczeni 1991; Füleky and Kovács 1993). Plots treated with the highest amount of fertilizer were investigated in the current research because the most pronounced changes occurred as a result of high fertilizer doses, as outlined in a previous examination (Harta et al. 2018).

To characterize the current developmental state of these two ca. 20-year-old forest plantations (LP, OP), we assigned five control sites to represent the adjacent cultivated (CA) and abandoned arable lands (AA), managed sessile oak (OC) and black locust (LC) forests, and an old-growth relict forest (RF). The structure of the black locust plantation (LP) is relatively open, with tree density of 2200 trees ha $^{-1}$ and canopy closure of approximately $50 \%$. The shrub layer is patchy (40-50\% cover), while the herb layer covers a minimum of $30 \%$ of the site and was dominated by the grass Bromus sterilis. The sessile oak plantation (OP) is more closed, with tree density of 3000 trees $^{-1}$ and canopy closure of $80-90 \%$. The shrub layer is less developed (20\% cover), and only a few herbaceous species appear in the sparse herb layer. Most of the characteristics of the managed 38-year-old control black locust forest (LC) are similar to those of the plantation; canopy closure is $45-50 \%$, and tree density is 1500 trees $\mathrm{ha}^{-1}$. The shrub layer cover is about $50 \%$, while the herb layer is dense, with a coverage of $60-70 \%$. The managed control oak forest (OC) is a two-storey stand, with tree density of 900 trees $\mathrm{ha}^{-1}$ and canopy closure of $90 \%$. Both shrub (50\%) and herb layers (60\%) are well developed. The old-growth forest (RF) is a relict association of Aceri campestris-Quercetum petraeae-roboris) endemic in this
Fig. 1 Map showing location of study area in Gödöllő, Central Hungary. Coloured circles represent the studied habitats (sites). Insert shows the size of replicates I-III with five random sampling plots set up within each site

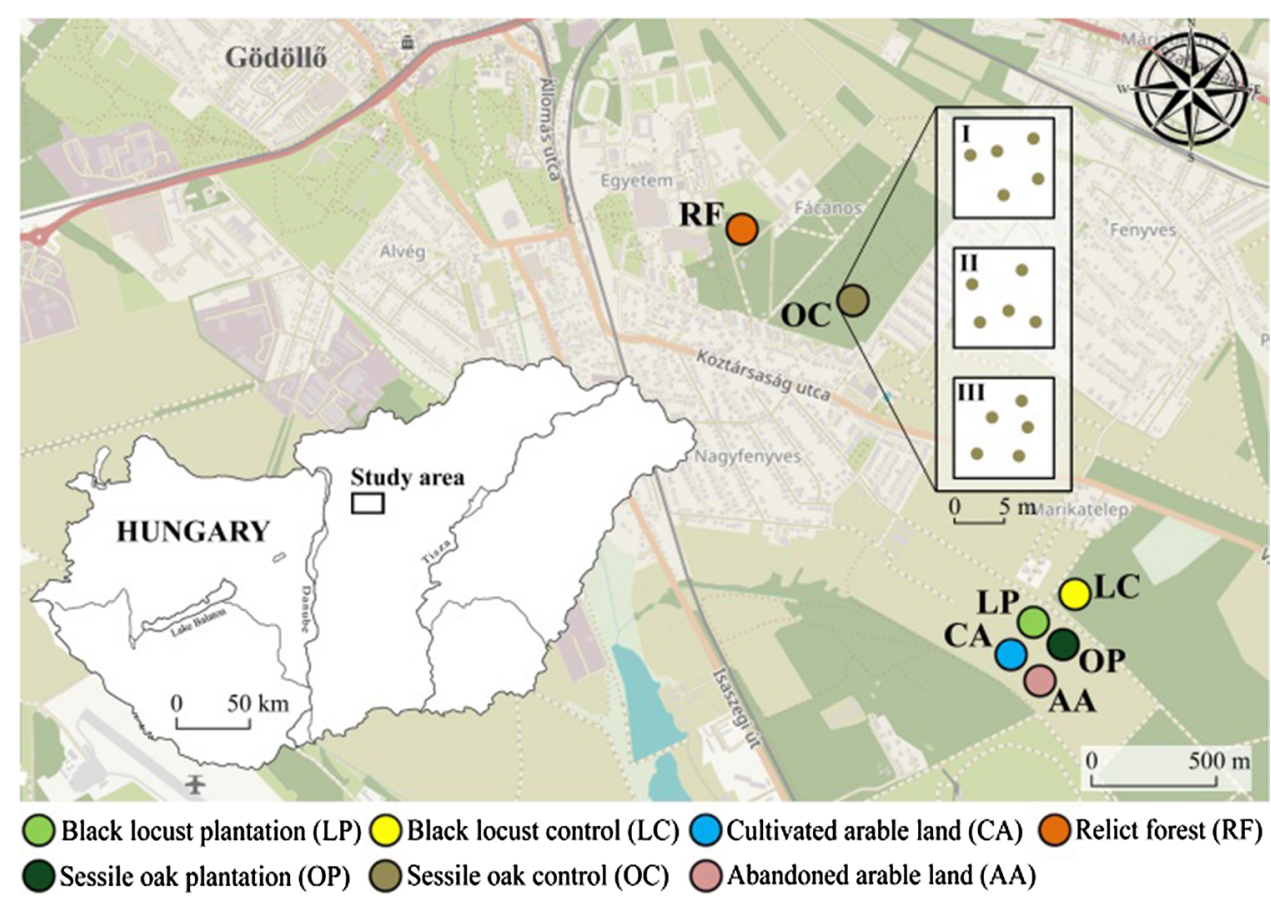


landscape. The two-layered forest stand has fairly welldeveloped, species-rich shrub and herb layers.

\section{Soil sampling and analysis}

After litter removal, soil samples were taken from the top $20 \mathrm{~cm}$ layer in September 2017. Each test site was represented by three replications $(10 \mathrm{~m} \times 10 \mathrm{~m}$ plots $)$, where one replication consisted of five randomly collected (Fig. 1) and then thoroughly mixed soil cores (ca. $50 \mathrm{~g}$ ). Samples were air-dried, crushed, and sieved through a $2.0-\mathrm{mm}$ grid. To compare our results to the results in older studies, we used the same analytical methods as described by Füleky and Debreczeni (1991) and Füleky and Kovács (1993). The $\mathrm{pH}$ was determined in distilled water $\left(\mathrm{pH}_{\mathrm{H} 2 \mathrm{O}}\right)$ and in KCl-suspension $\left(\mathrm{pH}_{\mathrm{KCl}}\right)$ as well, in a ratio of 1:2.5 using a potentiometric method. Soil organic matter (SOM) content was determined by the Tyurin (1931) method (wet oxidation by $\mathrm{K}_{2} \mathrm{Cr}_{2} \mathrm{O}_{7}$ and $\left.\mathrm{H}_{2} \mathrm{SO}_{4}\right)$. Mineral nitrogen $\left(\mathrm{NO}_{3}{ }^{-}+\mathrm{NH}_{4}{ }^{+}\right)$ forms were defined by Parnas-Wagner distillation using potassium-chloride $(1 \% \mathrm{KCl})$. Soluble phosphorus (AL$\mathrm{P})$ and potassium (AL-K) contents were extracted using ammonium-lactate-acetic acid and $\mathrm{Ca}$ and $\mathrm{Mg}$ contents with $1 \mathrm{M} \mathrm{KCl}$ solution (MSZ 20135 1999). Calcium carbonate $\left(\mathrm{CaCO}_{3}\right)$ content was measured with the Scheibler method according to the volume of released $\mathrm{CO}_{2}$ after diluted hydrochloric acid $(10 \% \mathrm{HCl})$ was added to the sample (Allison and Moodie 1965). The plasticity index according to Arany $\left(K_{\mathrm{A}}\right)$ was defined as well, which is the amount of distilled water (expressed in $\mathrm{dm}^{3}$ ) contained in $100 \mathrm{~g}$ air-dried soil at the upper limit of plasticity (Buzás 1993). This method is also appropriate to gain information on the water-holding capacity of the sampled soil.

\section{Sampling and extraction of Collembola}

Corresponding to the sampling design for determining soil properties (Fig. 1), five nondestructive soil samples of $100 \mathrm{~cm}^{3}$ were taken at a $10-\mathrm{cm}$ depth in each selected plot using a soil corer with a $3.6-\mathrm{cm}$ diameter. Mesofauna was extracted within 14 days from the soil samples into $70 \%$ ethanol at room temperature using unheated Berlese-Tullgren funnels. Collembola individuals were counted and identified to the species level (adult and young individuals except for those at the first instar stage). Taxonomic classification was primarily based on the checklist of Hungarian fauna (Dányi and Traser 2008).

Due to the uncertainties of species identity of Pseudosinella wahlgreni (see Stomp 1971), the Pseudosinella species with $5+5$ ocelli found in the control oak forests has been listed as Pseudosinella sp. wahlgreni-group based on the main morphological characters.

\section{Data analyses}

Habitat soil variables were tested for normality (Shapiro-Wilk test) and homogeneity of variances (Levene's test), then tested with a one-way ANOVA to test for differences among the seven studied sites. Significance level was set at $p<0.05$. Prior to this, the independence of cases was provided by collecting samples randomly. If Levene's test was significant $(p<0.05)$, the unequal variance (Welch $F$ test) version of ANOVA was used. Significant differences between the groups were evaluated by Tukey's pairwise post hoc test (Copenhaver and Holland 1988). If the required assumptions were strongly violated (normality test $p<0.05$ ), the nonparametric Kruskal-Wallis test was used (allowed rate $p<0.05$ ) with Dunn's pairwise post hoc test instead (raw $p$ values) (Dunn 1964).

Collembolan abundance was calculated as the number of individuals per square meter (ind. $\mathrm{m}^{-2}$ ). Two measures of diversity were computed: the Shannon index (Shannon and Weaver 1949); and Pielou's evenness index (Pielou 1966), respectively. To compare Shannon diversities, the Hutcheson $t$ test was used (Hutcheson 1970). Renyi diversity profiles, incorporating further diversity measures (e.g., species richness, Simpson index) apart from the Shannon index, were constructed to rank Collembola communities according to diversity (Tóthmérész 1997). A community of higher diversity is characterized by a profile that runs consistently higher than the profile of a less diverse community. The degree of dominance was expressed with McNaughton's dominance index (CDI) calculated as the percentage of abundance contributed by the two most abundant species (McNaughton 1967).

Principal coordinate analysis (PCoA) was performed to order the Collembola communities in the different habitat types (Legendre and Legendre 2012). The distance matrix calculated for PCoA was determined using the Bray-Curtis dissimilarity measure (Bray and Curtis 1957).

To explore potential relationships between Collembolan species composition and soil variables, a direct ordination method, canonical correspondence analysis (CCA) was applied with forward variable selection. To conduct the analysis, we used species abundance for the main matrix, while the environmental matrix included the variables $\mathrm{pH}$, SOM, mineral N, AL-P and AL-K. Species in less than 5 samples or represented by fewer than 10 specimens were not entered in the analysis to avoid misrepresentation of the sampling data. In parallel, an unrestricted Monte Carlo test was performed by considering 1000 random permutations to reveal the effect of the constraining variables used in the analysis. Statistical analyses were carried out using the software Past ver. 3.17 (Hammer et al. 2001) and CANOCO ver. 4.5 (ter Braak and Šmilauer 2002). 


\section{Results}

\section{Collembola communities}

In total, 11,410 specimens from 15 families, 40 genera, and 76 species were sampled and identified (Supplementary Table S1) at the seven study sites in the Gödöllő Hills. The greatest species richness was found in samples of the relict oak stand, while the lowest species richness was observed in the cultivated field (Table 1). Both the oak and black locust forest plantations supported higher species richness, and Shannon diversities were significantly higher when compared to the cultivated site $(t=16.843$ and 9.534, respectively, $p<0.001)$. Nevertheless, when compared to the control forest habitats, significantly lower diversity was observed in both plantations $(t=5.33-38.63, p<0.001)$. Marked difference was also found between the two plantation types $(t=10.65, p<0.001)$, where the soil of the native oak plantation supported a more diverse community. Renyi diversity profiles emphasized the same pattern (Fig. 2).

Apart from high species richness and diversity in the abandoned arable land, it had the most even community structure, which was also supported by the highest equitability $(J)$ and a relatively low mean community dominance index (CDI) value. Regarding abundance, we found significant difference among habitats (Kruskal-Wallis, $H=18.84$, $p<0.05$ ), and the difference between the cultivated arable field and young afforested habitat was more pronounced, averaging 2.5 times higher in the young plantations. Considering different types of forest plantations, although mean abundance was higher in the black locust plantation, a significant difference could not be observed (Dunn's, NS). Mean abundance was the highest in the old relict oak forest.

The PCoA ordination performed on the plot-to-plot dissimilarity matrix clearly separated the communities of the open habitats from those of the plantations and control forests (Fig. 3). Regarding the forest communities, there was a certain degree of overlap between the oak and black locust

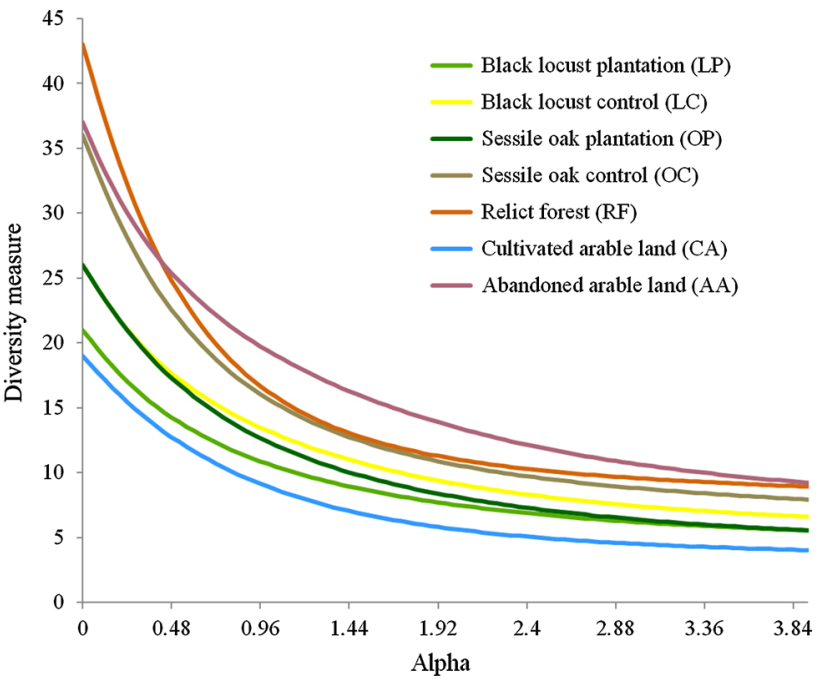

Fig. 2 Diversity profiles of the Collembolan communities. The profiles incorporate the exponential of the Rényi index, which indicates the total species richness for $\alpha=0$, an index proportional to the Shannon diversity for $\alpha=1$ and the logarithm of the reciprocal Simpson diversity for $\alpha=2$, respectively

plantations and between the managed control forests. The community of the old-growth relict forest showed a clear separation.

The result of the canonical correspondence analysis (CCA) provides more detailed information on species-habitat relationship (Fig. 4). The eigenvalue was significant for both axis $1(0.427)$ and axis $2(0.169)$, and the explained variance of both axes were also relatively high $(61.71 \%$ and $17.92 \%$, respectively). The Monte Carlo permutation test confirmed the significance of both axis 1 and axis $2(p<0.01$ and $p<0.05$, respectively). From the variables entered into the analysis, axis 1 mainly represents soil $\mathrm{pH}$, soluble phosphorus (AL-P), soil organic matter content (SOM), and plasticity $\left(K_{\mathrm{A}}\right)$, while axis 2 mostly represents mineral nitrogen $\left(\mathrm{NO}_{3}{ }^{-}+\mathrm{NH}_{4}{ }^{+}\right)$and soluble potassium content $(\mathrm{AL}-\mathrm{K})$.

Table 1 Mean abundance $( \pm \mathrm{SE})$ and site based community indices of Collembola (A: abundance (ind. $\left.\mathrm{m}^{-2}\right) ; S:$ species richness; $H^{\prime}:$ Shannon diversity index; $J$ : Pielou's evenness index; CDI: community dominance index)

\begin{tabular}{|c|c|c|c|c|c|c|c|}
\hline \multirow[t]{2}{*}{ Indices } & \multicolumn{2}{|l|}{ Reforested sites } & \multicolumn{2}{|l|}{ Control forests } & \multicolumn{3}{|l|}{ Agricultural lands } \\
\hline & OP & LP & $\mathrm{OC}$ & LC & RF & CA & $\mathrm{AA}$ \\
\hline A & $6067 \pm 320 \mathbf{a b}$ & $6433 \pm 254$ abc & $14040 \pm 711 \mathrm{~cd}$ & $11780 \pm 476$ bcd & $23033 \pm 1185 \mathbf{d}$ & $2633 \pm 279 \mathbf{a}$ & $\begin{array}{l}12033 \pm 1095 \\
\text { bed }\end{array}$ \\
\hline $\mathrm{S}$ & 26 & 21 & 36 & 26 & 43 & 18 & 37 \\
\hline $\mathrm{H}^{\prime}$ & 2.516 & 2.368 & 2.752 & 2.582 & 2.788 & 2.188 & 2.965 \\
\hline $\mathrm{J}$ & 0.772 & 0.778 & 0.768 & 0.793 & 0.741 & 0.743 & 0.821 \\
\hline CDI & 39.67 & 41.97 & 33.76 & 37.75 & 28.74 & 53.16 & 29.81 \\
\hline
\end{tabular}

In the case of abundance, bold letters (a, b, c and d) indicate significantly different groups after Dunn's test $(p<0.05)$. The same letter indicates that they belong to the same group. For sampling site abbreviations, see the legend of Fig. 1 


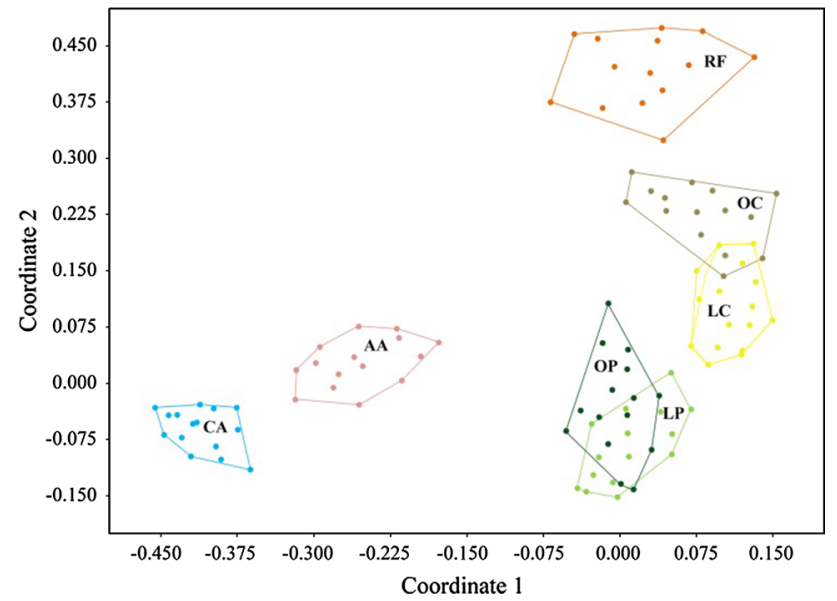

Fig. 3 Principal coordinate analysis ordination of Collembola communities from the forest plantations and control habitats using BrayCurtis distances. For sampling site abbreviations, see the legend of Fig. 1
Along the gradient of axis 1 , a clear habitat sequence can be observed from the open arable fields, through the young plantations toward the old relict forest. Along axis 2, the cultivated arable field exhibited a remarkable separation.

Collembola species characteristic for open habitats (e.g., Ceratophysella succinea, Lepidocyrtus paradoxus, Isotoma caerulea) are distributed toward the positive side of axis 1 , while species collected principally or exclusively in forests (e.g., Neanura muscorum, Entomobrya muscorum, Pseudosinella horaki) are ordinated on the negative side of the same axis. As shown by their ordination on the negative side of axis 2, species like Brachystomella parvula or Folsomides parvulus are also well adapted to unfavorable soil conditions (low organic matter content, higher fertilizer load) and are grouped near the cultivated arable field plots.

\section{Soil habitat condition}

Based on the measured soil variables, the studied habitats were characterized as sandy textured soils, with relatively acidic or neutral $\mathrm{pH}$ and lack of carbonates. Nevertheless, they had remarkable differences for most of the variables (Table 2$)$. Soil plasticity $\left(K_{\mathrm{A}}\right)$ values differed significantly

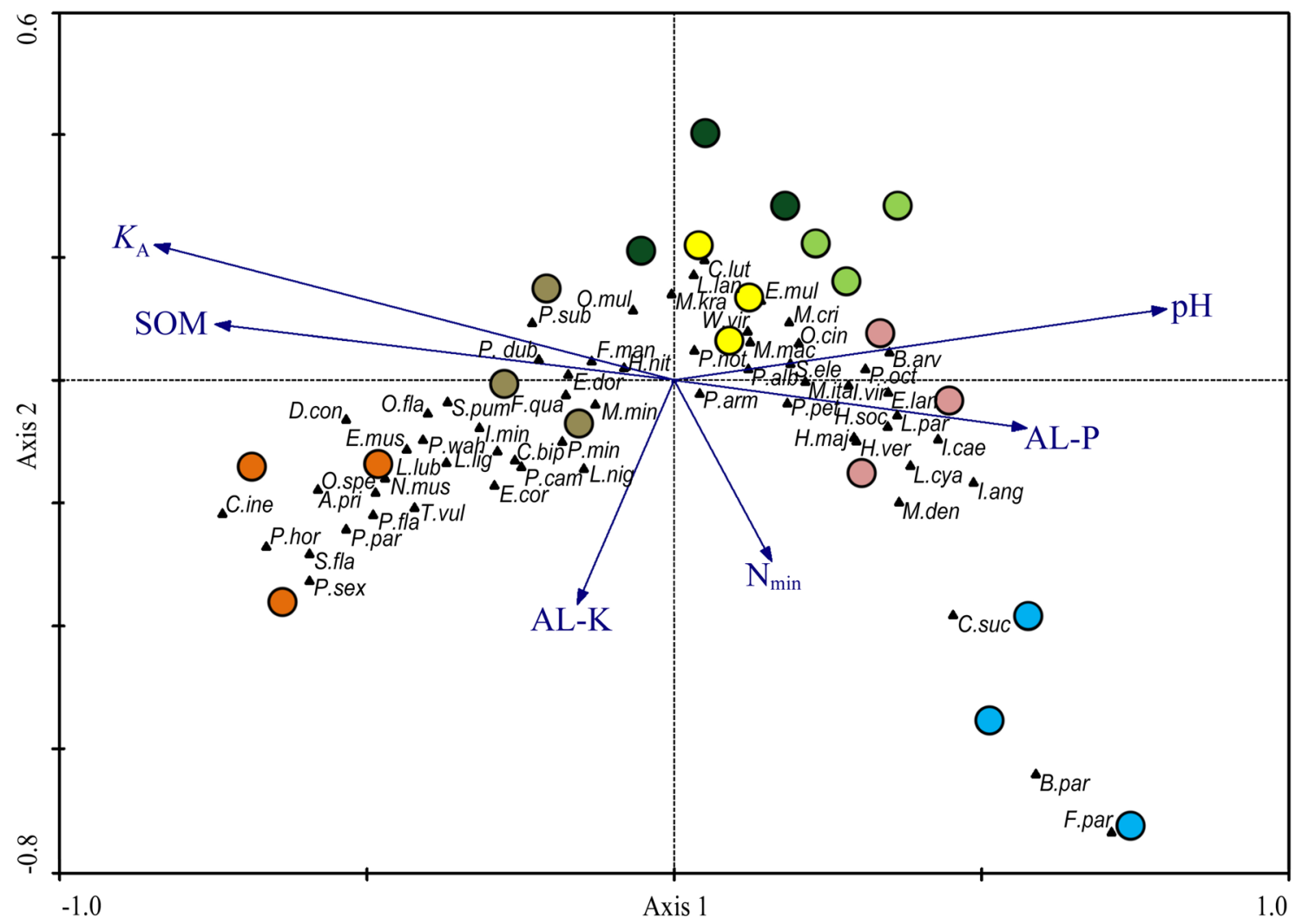

Fig. 4 Ordination biplot of canonical correspondence analysis with mean abundances of Collembola species and selected soil variables (SOM, soil organic matter content; $K_{\mathrm{A}}$, plasticity index according to Arany; soil $\mathrm{pH} ; \mathrm{N}_{\min }=\mathrm{NO}_{3}{ }^{-}+\mathrm{NH}_{4}{ }^{+}$, mineral nitrogen; AL-P, solu- ble phosphorus; AL-K, soluble potassium. For sampling site symbols (coloured circles), see Fig. 1. Collembola species abbreviations consist of the initial letter of the genus name, followed by the first three letters of the species name 
among habitats (Kruskal-Wallis, $H=18.18, p<0.01$ ). The highest values occurred in the RF and the lowest in the CA. Significant differences in soil organic matter (SOM) content were also observed among habitats (Kruskal-Wallis, $H=16.63, p<0.01$ ). As expected, the highest SOM content was found in the soil of the old-growth relict forest (RF), showing significant difference (Dunn's, $p<0.001$ ) from the cultivated land (CA). Nevertheless, the afforested sites (OP, LP) did not significantly differ from the control forests (Dunn's, NS). The $\mathrm{pH}_{\mathrm{H} 2 \mathrm{O}}$ values were $0.5<\mathrm{pH}$ unit higher than those of $\mathrm{pH}_{\mathrm{KCl}}$ in all habitats, indicating residual acidity. Significant differences were observed in both $\mathrm{pH}_{\mathrm{H} 2 \mathrm{O}}$ (ANOVA, $F=19.50, p<0.01$ ) and $\mathrm{pH}_{\mathrm{KCl}}$ (ANOVA, $F=54.53, p<0.001)$. The most acidic soil was associated with the old-growth relict forest (RF), while the highest $\mathrm{pH}$ occurred in the abandoned arable land (AA). Both types of $\mathrm{pH}$ values were also low in the sessile oak plantation, while the $\mathrm{pH}$ values in black locust plantation were similar to the open habitats (CA, AA) and the managed black locust control forest (Tukey's HSD test, NS). Significant differences were observed among habitats also in macronutrient contents, such as phosphorus (ANOVA, $F=14.89, p<0.001$ ), potassium (ANOVA, $F=7.82, p<0.001$ ) and mineral nitrogen (ANOVA, $F=4.61, p<0.01$ ).

\section{Discussion}

Our results for soil properties and Collembola community species composition, diversity, and abundance suggest that the studied forest plantations can be ranked as transitions among the cultivated arable field and the control forests. As the results of PCoA based on the Bray-Curtis dissimilarity (Fig. 3) revealed, the open control habitats (CA, AA) showed consistent separation from the forest plantations (OP, LP) and forest control habitats (OC, LC, RF). Destructive agricultural management practices, such as tillage, use of fertilizers and pesticides, alter soil structure and chemical properties leading to soil degradation, thereby negatively affecting the habitat of soil microarthropods, including Collembola (Cortet et al. 2002; Brussaard et al. 2007; Kalia and Gosal 2011; Wachira et al. 2014; Tsiafouli et al. 2015). Cultivation often causes organic carbon loss in soils (Collins et al. 2000; Song et al. 2005), which is demonstrated in the lowest SOM content in the studied cultivated agricultural land (CA). The low SOM content is coupled with low soil plasticity $\left(K_{\mathrm{A}}\right)$ values, indicating poor water retention ability and resulting dry conditions in this sandy soil. A high concentration of available phosphorus, caused by fertilization and facilitated decomposition due to tillage, was also expected (Lupwayi et al. 2007). The aforementioned practices and their implications on soil condition generally tend to reduce Collembola diversity (Frampton 1997; Giller et al. 1997; Alvarez et al. 2001; Gruss and Twardowski 2012; Twardowski et al. 2016). Decreased abundance and species richness are characteristic for arable habitats, as reported in several regions (e.g., Kováč and Miklisová 1997; Culik et al. 2002; Sousa et al. 2006; Vanbergen et al. 2007; Muturi et al. 2009). Thus, as expected, the lowest Collembola species richness, diversity, and abundance was found in the cultivated site (CA). Besides the mentioned alteration caused by agricultural practices, arable soils are also considered

Table 2 Measured soil variables (mean $\pm \mathrm{SD}$ ) in afforested sites and control habitats. $K_{\mathrm{A}}$ : plasticity index according to Arany, SOM: soil organic matter, $\mathrm{CaCO}_{3}$ : calcium-carbonate content, $\mathrm{N}$ min: $\mathrm{NO}_{3}{ }^{-}+\mathrm{NH}_{4}{ }^{+}$; mineral nitrogen content

\begin{tabular}{|c|c|c|c|c|c|c|c|}
\hline \multirow[t]{2}{*}{ Variable } & \multicolumn{2}{|l|}{ Reforested sites } & \multicolumn{3}{|l|}{ Control forests } & \multicolumn{2}{|c|}{ Agricultural lands } \\
\hline & OP & LP & $\mathrm{OC}$ & $\mathrm{LC}$ & RF & $\mathrm{CA}$ & AA \\
\hline$K_{\mathrm{A}} *$ & $27 \pm 1.0 \mathbf{a b}$ & $28 \pm 1.5 \mathbf{a b}$ & $32 \pm 1.0 \mathbf{b c}$ & $27 \pm 0.58 \mathbf{a b}$ & $44 \pm 4.2 \mathrm{c}$ & $21 \pm 0.58 \mathbf{a}$ & $33 \pm 2.1 \mathbf{b c}$ \\
\hline $\operatorname{SOM}(\%)^{*}$ & $2.11 \pm 0.28 \mathbf{b c}$ & $2.22 \pm 0.20 \mathbf{b c}$ & $2.01 \pm 0.22 \mathbf{a b}$ & $1.46 \pm 0.34 \mathbf{a b}$ & $3.97 \pm 1.60 \mathrm{c}$ & $0.83 \pm 0.27 \mathbf{a}$ & $2.19 \pm 0.04 \mathbf{b c}$ \\
\hline $\mathrm{pH} \mathrm{H} \mathrm{H}_{2} \mathrm{O}$ & $5.57 \pm 0.43 \mathbf{b}$ & $6.85 \pm 0.12 \mathbf{d}$ & $5.86 \pm 0.32 \mathbf{b c}$ & $6.68 \pm 0.52 \mathrm{~cd}$ & $4.56 \pm 0.32 \mathbf{a}$ & $6.27 \pm 0.04$ bcd & $7.07 \pm 0.34 \mathbf{d}$ \\
\hline $\mathrm{pH} \mathrm{KCl}$ & $4.56 \pm 0.59 \mathbf{a b}$ & $6.26 \pm 0.13$ de & $4.95 \pm 0.40 \mathbf{b c}$ & $6.05 \pm 0.74$ cde & $3.63 \pm 0.16 \mathbf{a}$ & $5.21 \pm 0.09$ bcd & $6.48 \pm 0.41 \mathbf{e}$ \\
\hline $\mathrm{CaCO}_{3}(\%)$ & $0.00 \pm 0.00$ & $0.00 \pm 0.00$ & $0.00 \pm 0.00$ & $1.83 \pm 3.16$ & $0.00 \pm 0.00$ & $0.00 \pm 0.00$ & $0.85 \pm 1.48$ \\
\hline $\mathrm{Ca}\left(\mathrm{mg} \mathrm{kg}^{-1}\right)^{*}$ & $265 \pm 86 \mathbf{a}$ & $671 \pm 16 \mathbf{b}$ & $456 \pm 27 \mathbf{a b}$ & $1452 \pm 1797 \mathbf{a b}$ & $323 \pm 145 \mathbf{a}$ & $431 \pm 13 \mathbf{a b}$ & $1878 \pm 2220 \mathbf{b}$ \\
\hline $\operatorname{Mg}\left(\mathrm{mg} \mathrm{kg}^{-1}\right)$ & $91.6 \pm 17.5$ abc & $101.7 \pm 10.5 \mathbf{b c}$ & $119.3 \pm 12.2 \mathbf{c}$ & $74.6 \pm 7.4 \mathbf{a b}$ & $87.1 \pm 12.2 \mathbf{a b}$ & $99.1 \pm 5.4 \mathbf{a b c}$ & $68.5 \pm 10.9 \mathbf{a}$ \\
\hline $\mathrm{AL}-\mathrm{P}\left(\mathrm{mg} \mathrm{kg}^{-1}\right)$ & $122 \pm 6 c$ & $20 \pm 13 \mathbf{a}$ & $12 \pm 10 \mathbf{a}$ & $38 \pm 7 \mathbf{a b}$ & $30 \pm 10 \mathbf{a b}$ & $44 \pm 9 \mathbf{a b}$ & $75 \pm 39$ bc \\
\hline $\mathrm{AL}-\mathrm{K}\left(\mathrm{mg} \mathrm{kg}^{-1}\right)$ & $224 \pm 36 \mathrm{~cd}$ & $156 \pm 16 \mathbf{a b c}$ & $105 \pm 34 \mathbf{a}$ & $121 \pm 1 \mathbf{a b}$ & $248 \pm 33$ d & $202 \pm 32$ bcd & $181 \pm 52$ abcd \\
\hline $\mathrm{NH}_{4}-\mathrm{N}\left(\mathrm{mg} \mathrm{kg}^{-1}\right)$ & $10.1 \pm 3.9 \mathbf{b}$ & $1.3 \pm 0.70 \mathbf{a}$ & $6.7 \pm 3.8 \mathbf{a b}$ & $3.6 \pm 1.9 \mathbf{a b}$ & $5.5 \pm 3.6 \mathbf{a b}$ & $3.4 \pm 1.3 \mathbf{a b}$ & $2.7 \pm 0.72 \mathbf{a}$ \\
\hline $\mathrm{NO}_{3}-\mathrm{N}\left(\mathrm{mg} \mathrm{kg}^{-1}\right)$ & $2.8 \pm 1.6 \mathbf{a}$ & $7.7 \pm 7.5 \mathbf{a}$ & $4.3 \pm 2.5 \mathbf{a}$ & $5.5 \pm 2.2 \mathbf{a}$ & $29.6 \pm 15.1 \mathbf{b}$ & $2.9 \pm 0.69 \mathbf{a}$ & $5.5 \pm 1.9 \mathbf{a}$ \\
\hline $\mathrm{N} \min \left(\mathrm{mg} \mathrm{kg}^{-1}\right)$ & $12.8 \pm 4.6 \mathbf{a b}$ & $9.0 \pm 7.3 \mathbf{a}$ & $10.9 \pm 5.7 \mathbf{a}$ & $9.0 \pm 1.7 \mathbf{a}$ & $35.1 \pm 18.2 \mathbf{b}$ & $6.3 \pm 0.67 \mathbf{a}$ & $8.2 \pm 2.6 \mathbf{a}$ \\
\hline
\end{tabular}

Bold letters $(\mathrm{a}, \mathrm{b}$ and $\mathrm{c})$ indicate significantly different groups after Tukey's or Dunn's test $(p<0.05)$. In the case of each parameter, the same letter indicates that they belong to the same group. If there is no letter, it means no significant difference was observed. Asterisk (*) indicate those comparisons made with Kruskal-Wallis test. For sampling site abbreviations see the legend of Fig. 1 
to be poor in resources, mainly due to the lack of abundant vegetation (plant residues, roots). Nevertheless, some species can also use alternative food resources like bacteria or fungi (Lagerlöf and Andrén 1991; Hiol et al. 1994). In the arable soil samples, several cosmopolitan species were collected (e.g., Brachystomella parvula, Ceratophysella succinea, Mesaphorura macrochaeta, Parisotoma notabilis, Entomobrya multifasciata, Folsomides parvulus, Lepidocyrtus cyaneus), which are often found in intensively managed arable soils (Kováč and Miklisová 1997; Filser et al. 2002; Debeljak et al. 2007; Twardowski et al. 2016) and are reportedly showing tolerance to unfavorable conditions (e.g., drought, low SOM content, high concentration of fertilizer components such as nitrogen or phosphorus) as suggested by the CCA ordination (Fig. 4).

The release from environmental stress associated with the agricultural practices will lead to a marked response of biomass (Chauvat et al. 2007). After a transition to grassland, the values of SOM can rapidly increase (McLauchlan et al. 2006; Liu et al. 2020), as the abandoned agricultural land (AA) has more than twofold SOM content compared to the cultivated one. It is associated with improved waterholding ability indicated by the higher value of plasticity. Under these changed conditions, the colonization rate is usually high, and the Collembola population often shows a rapid increase (Kaczmarek and Kajak 1997; Chauvat et al. 2007). The spontaneous successive ruderal vegetation in the abandoned arable site (AA) provided habitat for more abundant communities and also led to increased species diversity. The value of Shannon diversity even exceeded that of the relic forest (RF). Nevertheless, the intersection observed between the Rényi diversity profiles of the sampled oldgrowth forest and grassland on the abandoned site (Fig. 2) emphasizes that open and forest areas supports different Collembola communities that are not comparable based solely on diversity (Tóthmérész, 1997). Apart from the ubiquitous species already present in the cultivated site, further species (Hypogastrura vernalis, Entomobrya lanuginosa, Lepidocyrtus paradoxus, Isotoma viridis) characteristic for open ecosystems such as grasslands (Ponge 1993; Ponge et al. 2003; Chauvat et al. 2007) were detected which, however, have specific ecological requirements including denser vegetation cover or higher SOM content.

The abandonment of farmlands offers large areas suitable for afforestation (Young et al. 2005), and this option has also been used in our study area. Although C loss can occur after afforestation (Berthrong et al. 2009; Hoogmoed et al. 2012), organic $\mathrm{C}$ content usually increases when afforestation occurs on cropland (Guo and Gifford 2002; Paul et al. 2002; Laganière et al. 2010; Li et al. 2012). Although forest floors accumulate $\mathrm{C}$ quickly and mostly in labile form, the rate of mineral soil $\mathrm{C}$ accumulation is slow. The turnover of SOM depends on the chemical composition of the $\mathrm{C}$ compounds (labile or stable), as well as environmental factors and soil properties (Jandl et al. 2007). Although more stable heavy humic fractions increase 20 years after afforestation (Del Galdo et al. 2003), the persistence of SOM mainly depends on complex interactions with its biotic and abiotic environment (Schmidt et al. 2011). Consistent with the findings, SOM content of the examined afforested sites increased compared to the data before afforestation $(\mathrm{SOM}=1.22 \%$; Füleky and Kovács 1993). The values are a little higher than the managed control forests (OC, LC) and form a transition among the cultivated arable land and the relict forest (RF). As suggested by the plasticity $\left(\mathrm{K}_{\mathrm{A}}\right)$ values, water retention is not as effective as in the relict forest, but surpasses that of cultivated land. With larger amounts of accumulated organic matter and higher plasticity, forest soils tend to support more abundant and diverse Collembola communities (Ponge et al. 2003; Bardgett et al. 2005; Potapov et al. 2017), as has been observed in the studied forest control habitats including the old-growth relict forest (RF) and also the managed stands (OC, LC). Afforestation following abandonment of farming tends to increase the spatial heterogeneity of soil resources, usually resulting in higher species richness and abundance (Arbea and Jordana 1985; Bardgett et al. 2005). Soil mesofauna, including Collembola, can show rapid increase in abundance and biomass during the first few years after afforestation (Dunger 1968; Hasegawa 2006). Community composition changes are, however, usually slower, which might be related to the distance of source habitats and the presence of connection corridors, the limited dispersal ability and, hence, the lack of colonization of certain Collembola species (Salmon and Ponge 1998; Ponge et al. 2006; Auclerc et al. 2009). Epedaphic species are more capable of migrating actively on the soil surface (Alvarez et al. 2000), while active migration of euedaphic springtails is often limited to short distances and always dependent on the population density in the soil (Sjögren 1997; Ojala and Huhta 2001). The effects of landscape heterogeneity and the characteristics of the surrounding habitats are also of decisive importance (Sousa et al. 2004; Vanbergen et al. 2007).

In the two studied plantations (LP, OP), only a few forest species were recorded, while some species characteristic to open habitats are still present. Among the species observed in the plantations, Neanura muscorum, Ceratophysella luteospina, Entomobrya muscorum, Folsomia quadrioculata, Isotomiella minor, and Megalothorax minimus can be considered as forest specialist or forest-preferring species (Auclerc et al. 2009; Vanhée and Devigne 2018). Interestingly, the last species, Megalothorax minimus, is present in both plantations, despite the species' poor dispersal ability as described by Ponge et al. (2006). Our results corroborate the findings of previous studies (Dunger et al. 2002; Auclerc et al. 2009), reporting rapid colonization of this neelid species. The relatively high number of open-habitat species 
(e.g., Protaphorura campata, Entomobrya multifasciata, Lepidocyrtus cyaneus, Pseudosinella alba) recorded in the plantations clearly shows the impact of the surrounding habitats (cultivated fields, secondary grassland on abandoned farmland). The relatively young age of the plantations is also reflected in the dominance structure of the Collembola communities. In younger stages, the number of the non-abundant rare and accessorial species is usually lower, while distinct eudominance of singular species is often observable (Trojan et al. 1994; Vanhée and Devigne 2018) and well emphasized by the higher values of the community dominance index (CDI) in the plantations compared with the control oldgrowth relict forest.

Selecting suitable tree species (native vs. non-native) for afforestation is of great importance and also has a significant, long-term impact on the soil fauna (Deharveng 1996). Vegetation strongly influences Collembola diversity and abundance, mainly through the amount and quality of produced litter (Bezkorovaynaya 2005; Ma et al. 2020). Black locust is considered among the most invasive tree species in Europe (Campagnaro et al. 2018), especially in Hungary, where it comprises $25 \%$ of forest stands (Bartha 2000). Black locust has a diverse impact on soil properties, inter alia, by increasing nitrogen, nitrate, and SOM content (Lazzaro et al. 2018). The higher organic matter content is manifested in the slightly higher Collembola abundance observed in the black locust plantations when compared to the oak plantations. In terms of species richness, diversity, and equitability, their values were higher in the indigenous sessile oak plantation, which might be due to the allelopathic effect of the black locust. The secondary metabolites (e.g., phasin, robin or toxalbumins) released from the leaf litter of black locust have been proved to inhibit protein synthesis, providing unfavorable conditions for less-tolerant species (Rahmonov 2009; Lazzaro et al. 2018). Presumably, this phenomenon is responsible for the lower species richness and diversity found in the plantation of the non-native black locust as expressed by the diversity profiles (Fig. 2). In addition, community structure also shows a less even distribution among species in the black locust stand compared with the indigenous oak plantation, as emphasized in the higher $C D I$ index.

Generally, soil acidification occurs following afforestation. The main causing factors are the increased production and input of organic acids and redistribution and sequestration of cations such as $\mathrm{K}, \mathrm{Ca}$, and $\mathrm{Mg}$ from soil to biomass. Relocated cations are replaced on soil exchange sites by $\mathrm{H}^{+}$; thus, the base saturation is lowered and the proportions of ions adsorbed to the soil exchange complex are changed (Chen et al. 2000; Jobbágy and Jackson 2003; Ritter et al. 2003; Farley et al. 2008; Shaifullah et al. 2008; Berthrong et al. 2009). In the oak plantation (OC), moderately acidic soil was found, while in the black locust plantation (BL) slightly acidic to neutral conditions were observed. Some Collembola species have narrower, while others wider tolerance to soil $\mathrm{pH}$ change, and it is known that soil $\mathrm{pH}$ can cause great changes in Collembola community composition (Van Straalen and Verhoef 1997; Van Straalen 1998). However, the difference in $\mathrm{pH}$ between the two plantations is not yet noticeable in terms of species composition, as the communities of the two plantations show significant overlap in the PCoA analysis (Fig. 3). When the plantations are examined together with the controls, not only habitats but also some species are well separated along the $\mathrm{pH}$ gradient in the CCA biplot (Fig. 4), from the alkalophil Brachystomella parvula through the weakly subneutral species Orchesella cincta and Lepidocyrtus cyaneus to the acidophil Tomocerus vulgaris.

\section{Conclusion}

The present study demonstrated that conversion of formerly highly fertilized cultivated land to forest plantations has considerable impacts on the soil and its biota. After afforestation, Collembola communities showed clear responses in terms of composition, species richness, abundance, and diversity. Based on the community characteristics, the studied sessile oak and black locust plantations can be ranked as transitions among the cultivated arable field and the managed and old-growth forests selected as controls. Among the studied set of interacting parameters, Collembola communities were mainly driven by soil plasticity, soil organic matter, $\mathrm{pH}$ and phosphorus content and, to a lesser extent, by nitrogen and potassium content.

Opinions are divided on the impact forest plantations have on biodiversity (Bremer and Farley 2010; Liu et al. 2010). Depending on the tree species used, several studies found low levels of soil fauna diversity in plantations (e.g., Arbea and Jordana 1985; Deharveng 1996), while others suggest that forest plantations can contribute to restoration of forest species and thus to biodiversity conservation, especially in areas with poor agricultural soils (Hooper et al. 2005; Cunningham et al. 2015). When compared to nearby cultivated soils, our results showed improvement in terms of Collembola diversity especially in the native sessile oak plantation, suggesting the transformation of cultivated land to forest plantations of native tree species as a positive solution.

Acknowledgements We thank Frank Berger for language editing. This article was made in frame of EFOP-3.6.1-16-2016-00018 - "Improving the role of research+development+innovation in the higher education through institutional developments assisting intelligent specialization in Sopron and Szombathely". 
Funding Open access funding provided by University of Sopron.

Open Access This article is licensed under a Creative Commons Attribution 4.0 International License, which permits use, sharing, adaptation, distribution and reproduction in any medium or format, as long as you give appropriate credit to the original author(s) and the source, provide a link to the Creative Commons licence, and indicate if changes were made. The images or other third party material in this article are included in the article's Creative Commons licence, unless indicated otherwise in a credit line to the material. If material is not included in the article's Creative Commons licence and your intended use is not permitted by statutory regulation or exceeds the permitted use, you will need to obtain permission directly from the copyright holder. To view a copy of this licence, visit http://creativecommons.org/licenses/by/4.0/.

\section{References}

Allison LE, Moodie CD (1965) Volumetric calsimeter methods of soil analysis, part 2. Chemical and microbiological properties. In: Black CA (ed) American society of agronomy. Wisconsin: Inc. Publisher Madison, Washington, pp 1389-1392

Alvarez T, Frampton GK, Goulson D (2000) The role of hedgerows in the recolonisation of arable fields by epigeal Collembola. Pedobiologia 44:516-526. https://doi.org/10.1078/S0031 -4056(04)70068-2

Alvarez T, Frampton GK, Goulson D (2001) Epigeic Collembola in winter wheat under organic, integrated and conventional farm management regimes. Agr Ecosyst Environ 83:95-110. https:// doi.org/10.1016/S0167-8809(00)00195-X

Arbea JI, Jordana R (1985) Effectode una repoblacion con coniferas en un robledal de Navarra sobre los Colemholos edaficos. Bol Soc Port Entomol 2:277-286

Arneth A, Harrison SP, Zaehle S, Tsigaridis K, Menon S, Bartlein PJ, Feichter J, Korhola A, Kulmala M, O’Donnell D, Schurgers G, Sorvari S, Vesala T (2010) Terrestrial biogeochemical feedbacks in the climate system. Nat Geosci 3:525-532. https://doi. org/10.1038/ngeo905

Auclerc A, Ponge JF, Barot S, Dubs F (2009) Experimental assessment of habitat preference and dispersal ability of soil springtails. Soil Biol Biochem 41:1596-1604. https://doi.org/10.1016/j. soilbio.2009.04.017

Bardgett RD, Chan KF (1999) Experimental evidence that soil fauna enhance nutrient mineralization and plant nutrient uptake in montane grassland ecosystems. Soil Biol Biochem 31:10071014. https://doi.org/10.1016/S0038-0717(99)00014-0

Bardgett RD, Yeates GW, Anderson JM (2005) Patterns and determinants of soil biological diversity. In: Bardgett RD, Usher MB, Hopkins DW (eds) Biological diversity and function in soils. Cambridge University Press, Cambridge, pp 100-118

Bartha D (2000) Erdőterület csökkenések, fafaj változások a Kárpátmedencében. In: R Várkonyi Á (ed) Táj és történelem-Tanulmányok a történeti ökológia világából. Budapest: Osiris Kiadó, pp 11-24. (in Hungarian)

Berthrong ST, Jobbágy EG, Jackson RB (2009) A global metaanalysis of soil exchangeable cations, $\mathrm{pH}$, carbon, and nitrogen with afforestation. Ecol Appl 19:2228-2241. https://doi. org/10.1890/08-1730.1

Bezkorovaynaya IN (2005) The formation of soil invertebrate communities in the Siberian afforestation experiment. In: Binkley D, Menyailo O (eds) Tree species effects on soils: implications for global change. Springer, Dordrecht, pp 307-316

Bonan GB (2008) Forests and climate change: forcings, feedbacks, and the climate benefits of forests. Science 320:1444-1449. https:// doi.org/10.1126/science. 1155121
Bouwman AF, Leemans R (1995) The role of forest soils in the global carbon cycle. In: McFee WF, Kelly FM (eds) Carbon forms and functions in forest soils. Madison, Soil Science Society of America, pp 503-525

Bray JR, Curtis JT (1957) An ordination of the upland forest communities of Southern Wisconsin. Ecol Monogr 27:325-349. https:// doi.org/10.2307/1942268

Bremer LL, Farley KA (2010) Does plantation forestry restore biodiversity or create green deserts? A synthesis of the effects of land-use transitions on plant species richness. Biodivers Conserv 19:3893-3915. https://doi.org/10.1007/s10531-010-9936-4

Brussaard L, de Ruiter PC, Brownc GB (2007) Soil biodiversity for agricultural sustainability. Agr Ecosyst Environ 121:233-244. https://doi.org/10.1016/j.agee.2006.12.013

Buzás I (ed) (1993) Soil—and agrochemical methods manual. Part 1. INDA 4231. Kiadó, Budapest, p 357 (in Hungarian)

Campagnaro T, Brundu G, Sitzia T (2018) Five major invasive alien tree species in European Union forest habitat types of the Alpine and Continental biogeographical regions. J Nat Conserv 43:227-238. https://doi.org/10.1016/j.jnc.2017.07.007

Canadell JG, Raupach MR (2008) Managing forests for climate change mitigation. Science 320:1456-1457. https://doi. org/10.1126/science. 1155458

Chauvat M, Wolters V, Dauber J (2007) Response of collembolan communities to land-use change and grassland succession. Ecography 3:183-192. https://doi.org/10.111 1/j.2007.0906-7590.04888.x

Chen CR, Condron LM, Davis MR, Sherlock RR (2000) Effects of afforestation on phosphorus dynamics and biological properties in a New Zealand grassland soil. Plant Soil 220:151-163. https://doi.org/10.1023/A:1004712401721

Chen CR, Condron LM, Xu ZH (2008) Impacts of grassland afforestation with coniferous trees on soil phosphorus dynamics and associated microbial processes: a review. Forest Ecol Manag 255:396-409. https://doi.org/10.1016/j.foreco.2007.10.040

Collins HP, Elliott ET, Paustian K, Bundy LG, Dick WA, Huggins DR, Smucker AJM, Paul EA (2000) Soil carbon pools and fluxes in long-term corn belt agroecosystems. Soil Biol Biochem 32:157-168. https://doi.org/10.1016/S0038 -0717(99)00136-4

Copenhaver MD, Holland B (1988) Computation of the distribution of the maximum studentized range statistic with application to multiple significance testing of simple effects. J Stat Comput Sim 30:1-15

Cortet J, Ronce D, Poinsot-Balaguer N, Beaufreton C, Chabert A, Viaux P, de Fonseca JPC (2002) Impacts of different agricultural practices on the biodiversity of microarthropod communities in arable crop systems. Eur J Soil Biol 38:239-244. https:// doi.org/10.1016/S1164-5563(02)01152-4

Culik MP, Souza JL, Ventura JA (2002) Biodiversity of Collembola in tropical agricultural environments of Espírito Santo, Brazil. Appl Soil Ecol 21:49-58. https://doi.org/10.1016/S0929 -1393(02)00048-3

Cunningham SC, Mac Nally R, Baker PJ, Cavagnaro TR, Beringer J, Thomson JR, Thompson RM (2015) Balancing the environmental benefits of reforestation in agricultural regions. Perspect Plant Ecol 17:301-317. https://doi.org/10.1016/j.ppees.2015.06.001

Dányi L, Traser G (2008) An annotated checklist of the springtail fauna of Hungary (Hexapoda: Collembola). Opuscula Zool 38:3-82

Debeljak M, Cortet J, Demšar D, Krogh PH, Džeroski D (2007) Hierarchical classification of environmental factors and agricultural practices affecting soil fauna under cropping systems using Bt maize. Pedobiologia 51:229-238. https://doi.org/10.1016/j.pedobi.2007.04.009

Deharveng L (1996) Soil Collembola diversity, endemism, and reforestation: a case study in the Pyrenees (France). Conserv Biol 10:74-84. https://doi.org/10.1046/j.1523-1739.1996.10010074.x 
Del Galdo I, Six J, Peressotti A, Cotrufo MF (2003) Assessing the impact of land-use change on soil $\mathrm{C}$ sequestration in agricultural soils by means of organic matter fractionation and stable $\mathrm{C}$ isotopes. Glob Change Biol 9:1204-1213. https://doi.org/10.10 46/j.1365-2486.2003.00657.x

Demeny K, Centeri C (2008) Habitat loss, soil and vegetation degradation by land use change in the Gödölló Hillside, Hungary. Cereal Res Commun 36:1739-1742

Deng Q, McMahon DE, Xiang Y, Yu CL, Jackson RB, Hui D (2017) A global meta-analysis of soil phosphorus dynamics after afforestation. New Phytol 213:181-192. https://doi.org/10.1111/ nph. 14119

Dövényi Z (ed) (2010) Inventory of microregions in Hungary. HAS Geographical Research Institute, Budapest, p 876 (in Hungarian)

Dunger W (1968) Die Entwicklung der Bodenfauna auf rekultivierten Kippen und Halden des Braunkohlentagesbaues. Abh Ber Naturkundemus Görlitz 43:1-256

Dunger W, Schulz H-J, Zimdars B (2002) Colonization behaviour of Collembola under different conditions of dispersal. Pedobiologia 46:316-327. https://doi.org/10.1078/0031-4056-00139

Dunn OJ (1964) Multiple comparisons using rank sums. Technometrics 6:241-252

Farley KA, Kelly EF (2004) Effects of afforestation of a páramo grassland on soil nutrient status. Forest Ecol Manag 195:281-290. https://doi.org/10.1016/j.foreco.2003.12.015

Farley KA, Jobbágy EG, Jackson RB (2005) Effects of afforestation on water yield: a global synthesis with implications for policy. Glob Change Biol 11:1565-1576. https://doi.org/10.11 11/j.1365-2486.2005.01011.x

Farley KA, Piñeiro G, Palmer SM, Jobbágy EG, Jackson RB (2008) Stream acidification and base cation losses with grassland afforestation. Water Resour Res 44:W00A03. https://doi. org/10.1029/2007WR006659

Filser J, Mebes KH, Winter K, Lang A, Kampichler C (2002) Longterm dynamics and interrelationships of soil Collembola and microorganisms in an arable landscape following land use change. Geoderma 105:201-221. https://doi.org/10.1016/S0016 $-7061(01) 00104-5$

Frampton GK (1997) The potential of Collembola as indicators of pesticide usage: evidence and methods from the UK arable ecosystem. Pedobiologia 41:179-184

Füleky G, Debreczeni B (1991) Nutrient accumulation in the soil of a 17-year maize monoculture. Agrokem Talajt 40:119-130

Füleky G, Kovacs K (1993) Effects of fertilization in long-term trials on brown forest soil at Gödöllő III - Soil Properties. Növénytermelés 42:527-537 (in Hungarian)

Gao Y, Dang P, Zhao Z (2018) Effects of afforestation on soil carbon and its fractions: a case study from the Loess Plateau, China. J For Res 29:1291-1297. https://doi.org/10.1007/s11676-017-0552-y

Gibbs HK, Ruesch AS, Achard F, Clayton MK, Holmgren P, Ramankutty N, Foley JA (2010) Tropical forests were the primary sources of new agricultural land in the 1980s and 1990s. Proc Natl Acad Sci Usa 107:16732-16737. https://doi.org/10.1073/ pnas.0910275107

Giller KE, Beare MH, Lavelle P, Izac AM, Swift MJ (1997) Agricultural intensification, soil biodiversity and agroecosystem function. Appl Soil Ecol 6:3-16. https://doi.org/10.1016/S0929 -1393(96)00149-7

Gruss IA, Twardowski JP (2012) Quantitative and ecological characteristic of springtails (Hexapoda: Collembola) assemblages on winter rye field, cultivated in a long-term monoculture and fivecrop rotation. J Res Appl Agric Engng 57:129-132

Guo LB, Gifford RM (2002) Soil carbon stocks and land use change: a meta analysis. Glob Change Biol 8:345-360. https://doi.org/1 0.1046/j.1354-1013.2002.00486.x
Hammer Ř, Harper DAT, Ryan PD (2001) PAST: paleontological statistics software package for education and data analysis. Palaeontol Electron 4:1-9

Harta I, Winkler D, Füleky G (2018) Impact of former long-term fertilization on springtail communities in a reforested experimental area. Columella 5:13-25. https://doi.org/10.18380/SZIE. COLUM.2018.5.1.13

Hasegawa M, Fukuyama K, Makino SI, Okochi I, Goto H, Mizoguchi T, Sakata T, Tanaka H (2006) Collembolan community dynamics during deciduous forests regeneration in Japan. Pedobiologia 50:117-126. https://doi.org/10.1016/j.pedobi.2005.12.003

Heiniger C, Barot S, Ponge J-F, Salmon S, Botton-Divet L, Carmignac D, Dubs F (2014) Effect of habitat spatiotemporal structure on collembolan diversity. Pedobiologia 57(2):103-117

Hiol FH, Dixton RK, Curl EA (1994) The feeding preference of mycophagous Collembola varies with the ectomycorrhizal symbiont. Mycorrhiza 5:99-103. https://doi.org/10.1007/BF00202340

Hoogmoed M, Cunningham SC, Thomson JR, Baker PJ, Beringer J, Cavagnaro TR (2012) Does afforestation of pastures increase sequestration of soil carbon in Mediterranean climates? Agr Ecosyst Environ 159:176-183. https://doi.org/10.1016/j. agee.2012.07.011

Hooper DU, Chapin FS, Ewel JJ, Hector A, Inchausti P, Lavorel S, Lawton JH, Lodge DM, Loreau M, Naeem S, Schmid B, Setala H, Symstad AJ, Vandermeer J, Wardle DA (2005) Effects of biodiversity on ecosystem functioning: a consensus of current knowledge. Ecol Monogr 75:3-35. https://doi. org/10.1890/04-0922

Hopkin SP (1997) Biology of the Springtails (Insecta: Collembola). Oxford University Press, Oxford, p 330

Huang Z, Ouyang Z, Li F, Zheng H, Wang X (2010) Response of runoff and soil loss to reforestation and rainfall type in red soil region of southern China. J Environ Sci 22:1765-1773. https ://doi.org/10.1016/S1001-0742(09)60317-X

Hutcheson K (1970) A test for comparing diversities based on the Shannon formula. J Theor Biol 29:151-154

IUSS Working Group (2014) World reference base for soil resources 2014 international soil classification system for naming soils and creating legends for soil maps. FAO, Rome, p 298

Jandl R, Lindner M, Vesterdal L, Bauwens B, Baritz R, Hagedorn F, Johnson DW, Minkkinen K, Byrne KA (2007) How strongly can forest management influence soil carbon sequestration? Geoderma 137:253-268. https://doi.org/10.1016/j.geode rma.2006.09.003

Jobbágy EG, Jackson RB (2003) Patterns and mechanisms of soil acidification in the conversion of grasslands to forests. Biogeochemistry 64:205-229. https://doi.org/10.1023/A:10249 85629259

Jongman RHG (2002) Homogenisation and fragmentation of the European landscape: ecological consequences and solutions. Landsc Urban Plan 58(2-4):211-221

Kaczmarek M, Kajak A (1997) Microarthropods and decomposition processes in meadows of various plant species richness. Ekologia Polska 45:795-813

Kalia A, Gosal SK (2011) Effect of pesticide application on soil microorganisms. Archiv Agr Soil Sci 57:569-596. https://doi. org $/ 10.1080 / 03650341003787582$

Kaneda S, Kaneko N (2008) Collembolans feeding on soil affect carbon and nitrogen mineralization by their influence on microbial and nematode activities. Biol Fert Soils 44:435-442. https://doi. org/10.1007/s00374-007-0222-x

Kladivko EJ (2001) Tillage systems and soil ecology. Soil Till Res 61:61-76. https://doi.org/10.1016/S0167-1987(01)00179-9

Konkoly-Gyuró É, Balázs P (2016) Forest cover change in the Carpathian Basin from the mid 19th century till nowadays. Bull For Sci 6:79-97. https://doi.org/10.17164/EK.2016.007 
Kováč L, Miklisová D (1997) Collembolan communities (Hexapoda: Collembola) in arable soils of East Slovakia. Pedobiologia 41:62-68

KSH (2019) Hungarian central statistical office: dissemination database. https://statinfo.ksh.hu/Statinfo/ Accessed 14 March 2014

Laganière J, Angers DA, Pare D (2010) Carbon accumulation in agricultural soils after afforestation: a meta-analysis. Glob Change Biol 16:439-453. https://doi.org/10.111 1/j.1365-2486.2009.01930.x

Lagerlöf J, Andrén O (1991) Abundance and activity of Collembola, Protura, and Diplura (Insecta, Apterygota) in four cropping systems. Pedobiologia 35:337-350

Lal R (2004) Soil carbon sequestration impacts on global climate change and food security. Science 304:1623-1627. https://doi. org/10.1126/science.1097396

Laurance WF, Sayer J, Cassman KG (2014) Agricultural expansion and its impacts on tropical nature. Trends Ecol Evol 29:107-116. https://doi.org/10.1016/j.tree.2013.12.001

Law BE, Hudiburg TW, Berner LT, Kent JJ, Buotte PC, Harmon ME (2018) Land use strategies to mitigate climate change in carbon dense temperate forests. Proc Natl Acad Sci USA 115:36633668. https://doi.org/10.1073/pnas.1720064115

Lawson SS, Michler CH (2014) Afforestation, restoration and regeneration-not all trees are created equal. J For Res 25:3-20. https://doi.org/10.1007/s11676-014-0426-5

Lazzaro L, Mazza G, d'Errico G, Fabiani A, Giuliani C, Inghilesi AF, Lagomarsino A, Landi S, Lastrucci L, Pastorelli R, Roversi PF, Torrini G, Tricarico E, Foggi B (2018) How ecosystems change following invasion by Robinia pseudoacacia: insights from soil chemical properties and soil microbial, nematode, microarthropod and plant communities. Sci Total Environ 622-623:1509-1518. https://doi.org/10.1016/j.scito tenv.2017.10.017

Legendre P, Legendre L (2012) Numerical ecology, 3 English. Elsevier, Amsterdam, p 1006

Li DZ, Niu SL, Luo YQ (2012) Global patterns of the dynamics of soil carbon and nitrogen stocks following afforestation: a meta-analysis. New Phytol 195:172-181. https://doi.org/10.1 111/j.1469-8137.2012.04150.x

Lindenmayer DB, Hobbs RJ (2004) Fauna conservation in Australian plantation forests-a review. Biol Conserv 119:151-168. https ://doi.org/10.1016/j.biocon.2003.10.028

Liu Q, Yin H, Cheng X, Lin B, Hu R, Zhao C, Yin C (2010) Problems and strategies of sustainable regeneration of plantation ecosystem in China. World For Res 23:71-75

Liu M, Han G, Zhang Q (2020) Effects of agricultural abandonment on soil aggregation, soil organic carbon storage and stabilization: Results from observation in a small karst catchment. Southwest China Agr Ecosyst Environ 288:106719. https://doi. org/10.1016/j.agee.2019.106719

Lupwayi NZ, Clayton GW, O’Donovan JT, Harker KN, Turkington TK, Soon YK (2007) Phosphorus release during decomposition of crop residues under conventional and zero tillage. Soil Till Res 95:231-239. https://doi.org/10.1016/j.still.2007.01.007

Luyssaert S, Schulze ED, Börner A, Knohl A, Hessenmöller D, Law BE, Ciais P, Grace J (2008) Old-growth forests as global carbon sinks. Nature 455:213. https://doi.org/10.1038/nature0727 6

Ma C, Yin X, Xu H, Tao Y (2020) Responses of soil Collembolans to vegetation restoration in temperate coniferous and broadleaved mixed forests. J For Res 31(6):2333-2345. https://doi. org/10.1007/s11676-019-01005-9

Mackey B, Prentice IC, Steffen W, House JI, Lindenmayer D, Keith H, Berry S (2013) Untangling the confusion around land carbon science and climate change mitigation policy. Nat Clim Change 3:552. https://doi.org/10.1038/NCLIMATE1804
McLauchlan KK, Hobbie SE, Post WM (2006) Conversion from agriculture to grassland builds soil organic matter on decadal timescales. Ecol Appl 16:143-153. https://doi.org/10.1890/04-1650

McNaughton SJ (1967) Relationship among functional properties of California grassland. Nature 216:168-169

Menta C, Conti FD, Pinto S, Bodini A (2018) Soil biological quality index (QBS-ar): 15 years of application at global scale. Ecol Ind 85:773-780. https://doi.org/10.1016/j.ecolind.2017.11.030

MSZ 20135 (1999) Determination of the soluble nutrient element content of the soil. Hungarian Standards Institution, Budapest, p 12 (In Hungarian)

Munteanu C, Kuemmerle T, Boltiziar M, Butsic V, Gimmi U, Halada L, Kaim D, Király G, Konkoly-Gyúró É, Kozak J, Lieskovský J, Mojses M, Müller D, Ostafin K, Ostapowicz K, Shandra O, Stych P, Walker S, Radeloff VC (2014) Forest and agricultural land change in the Carpathian region-a meta-analysis of long-term patterns and drivers of change. Land Use Policy 38:685-697. https://doi.org/10.1016/j.landusepol.2014.01.012

Muturi JJ, Mbugi JP, Mueke JM, Lagerlóf J, Mungatu JK, Nyamasyo D, Gikungu M (2009) Collembola density and diversity along a gradient of land-use types in Embu district, Eastern Kenya. Trop Subtrop Agroecosyst 11:361-369

Ojala R, Huhta V (2001) Dispersal of microarthropods in forest soil. Pedobiologia 45:443-450. https://doi. org/10.1078/0031-4056-00098

Pan Y, Birdsey RA, Fang J, Houghton R, Kauppi PE, Kurz WA, Phillips OL, Shvidenko A, Lewis SL, Canadell JG, Ciais P, Jackson RB, Pacala S, McGuire AD, Piao S, Rautiainen A, Sitch S, Hayes D (2011) A large and persistent carbon sink in the world's forests. Science 333:988-993. https://doi.org/10.1126/science.1201609

Paul KI, Polglase PJ, Nyakuengama JG, Khanna PK (2002) Change in soil carbon following afforestation. Forest Ecol Manag 168:241257. https://doi.org/10.1016/S0378-1127(01)00740-X

Paul D, Nongmaithem A, Jha LK (2011) Collembolan density and diversity in a forest and an agroecosystem. Open J Soil Sci 1:54 60. https://doi.org/10.4236/ojss.2011.12008

Paul KI, Cunningham SC, England JR, Roxburgh SH, Preece ND, Lewis T, Brooksbank K, Crawford DF, Polglase PJ (2016) Managing reforestation to sequester carbon, increase biodiversity potential and minimize loss of agricultural land. Land Use Policy 51:135-149. https://doi.org/10.1016/j.landusepol.2015.10.027

Pawson SM, Brin A, Brockerhoff EG, Lamb D, Payn TW, Paquette A, Parrotta JA (2013) Plantation forests, climate change and biodiversity. Biodivers Conserv 22:1203-1227. https://doi. org/10.1007/s10531-013-0458-8

Peng SS, Piao S, Zeng Z, Ciais P, Zhou L, Li LZX, Myneni RB, Yin Y, Zeng H (2014) Afforestation in China cools local land surface temperature. P Natl Acad Sci Usa 111:2915-2919. https://doi. org/10.1073/pnas.1315126111

Pielou EC (1966) The measurement of diversity in different types of biological collections. J Theor Biol 13:131-144. https://doi. org/10.1016/0022-5193(66)90013-0

Ponge JF (1993) Biocenoses of Collembola in atlantic temperate grasswoodland ecosystems. Pedobiologia 37:223-244

Ponge J-F, Gillet S, Dubs F, Fedoroff E, Haese L, Sousa JP, Lavelle P (2003) Collembolan communities as bioindicators of land use intensification. Soil Biol Biochem 35:813-826. https://doi. org/10.1016/S0038-0717(03)00108-1

Ponge J-F, Dubs F, Gillet S, Sousa JP, Lavelle P (2006) Decreased biodiversity in soil springtail communities: the importance of dispersal and landuse history in heterogeneous landscapes. Soil Biol Biochem 38:1158-1161. https://doi.org/10.1016/j.soilb io.2005.09.004

Poschlod P, Bakker JP, Kahmen S (2005) Changing land use and its impact on biodiversity. Basic Appl Ecol 6(2):93-98 
Potapov AM, Goncharov AA, Semenina EE, Korotkevich AY, Tsurikov SM, Rozanova OL, Anichkin AE, Zuev AG, Samoylova ES, Semenyuk II, Yevdokimov IV, Tiunov AV (2017) Arthropods in the subsoil: abundance and vertical distribution as related to soil organic matter, microbial biomass and plant roots. Eur J Soil Biol 82:88-97. https://doi.org/10.1016/j.ejsobi.2017.09.001

Rahmonov O (2009) The chemical composition of plant litter of black locust (Robinia pseudoacacia L.) and its ecological role in sandy ecosystems. Acta Ecol Sin 29:237-243. https://doi.org/10.1016/j. chnaes.2009.08.006

Ritter E, Vesterdal L, Gundersen P (2003) Changes in soil properties after afforestation of former intensively managed soils with oak and Norway spruce. Plant Soil 249:319-330. https://doi. org/10.1023/A:1022808410732

Rogelj J, Meinshausen M, Knutti R (2012) Global warming under old and new scenarios using IPCC climate sensitivity range estimates. Nat Clim Change 2:248. https://doi.org/10.1038/NCLIM ATE1385

Rogelj J, Popp A, Calvin KV, Luderer G, Emmerling J, Gernaat D, Fujimori S, Strefler J, Hasegawa T, Marangoni G, Krey V, Kriegler E, Riahi K, Vuuren DP, Doelman J, Drouet L, Edmonds J, Fricko O, Harmsen N, Havlík P, Humpenöder F, Stehfest E, Tavoni M (2018) Scenarios towards limiting global mean temperature increase below $1.5^{\circ} \mathrm{C}$. Nat Clim Change 8:325. https:// doi.org/10.1038/s41558-018-0091-3

Salmon S, Ponge JF (1998) Responses to light in a soil-dwelling springtail. Eur J Soil Biol 34:199-201. https://doi.org/10.1016/ S1164-5563(00)86662-5

Schmidt MW, Torn MS, Abiven S, Dittmar T, Guggenberger G, Janssens IA, Kleber M, Kögel-Knabner I, Lehmann J, Manning DAC, Nannipieri P, Rasse DP, Weiner S, Trumbore SE (2011) Persistence of soil organic matter as an ecosystem property. Nature 478:49-56. https://doi.org/10.1038/nature10386

Shaifullah KM, Mezbahuddin M, Sujauddin M, Haque SMS (2008) Effects of coastal afforestation on some soil properties in Lakshmipur coast of Bangladesh. J For Res 19:32-36. https://doi. org/10.1007/s11676-008-0005-8

Shaifullah KM, Sirajul Haque SM, Sujauddin M, Karmakar S (2009) Coastal afforestation effects on soil properties at Hatiya in Bangladesh. J For Res 20:243-248. https://doi.org/10.1007/s1167 6-009-0035-x

Shannon CE, Weaver W (1949) The mathematical theory of communication. University of Illionis Press, Urbana, p 117

Sjögren M (1997) Dispersal rates of Collembola in metal polluted soil. Pedobiologia 41:506-513

Song G, Li L, Pan G, Zhang Q (2005) Topsoil organic carbon storage of China and its loss by cultivation. Biogeochemistry 74:47-62. https://doi.org/10.1007/s10533-004-2222-3

Sousa JP, Da Gama MM, Pinto C, Keating A, Calhôa F, Lemos M, Castro C, Luz T, Leitão P, Dias S (2004) Effects of land-use on Collembola diversity patterns in a Mediterranean landscape. Pedobiologia 48:609-622. https://doi.org/10.1016/j.pedob i.2004.06.004

Sousa JP, Bolger T, Da Gama MM, Lukkari T, Ponge J-F, Simón C, Traser G, Vanbergen AJ, Brennan A, Dubs F, Ivitis E, Keating A, Stofer S, Watt AD (2006) Changes in Collembola richness and diversity along a gradient of land-use intensity: a pan European study. Pedobiologia 50:147-156. https://doi.org/10.1016/j.pedob i.2005.10.005

Stomp N (1971) Contribution à l'étude des Pseudosinella endogés. Espèces européennes de Pseudosinella à 5+5 yeux (Collembola, Entomobryidae). Rev Ecol Biol Sol 1:173-178

ter Braak CJF, Śmilauer P (2002) CANOCO reference manual and Canodraw for windows user's guide: software for canonical community ordination (version 4.5). Microcomputer Power, Ithaca, p 500
Tews J, Brose U, Grimm V, Tielborger K, Wichmann MC, Schwager M, Jeltsch F (2004) Animal species diversity driven by habitat heterogeneity/diversity: the importance of keystone structures. J Biogeogr 31:79-92. https://doi.org/10.1046/j.0305-0270.2003.00994 .X

Torralba M, Fagerholm N, Burgess PJ, Moreno G, Plieninger T (2016) Do European agroforestry systems enhance biodiversity and ecosystem services? A meta-analysis. Agr Ecosyst Environ 230:150 161. https://doi.org/10.1016/j.agee.2016.06.002

Tóthmérész B (1997) Diversity orderings. Scientia, Budapest, p 98 (In Hungarian)

Trojan P, Bańkowska R, Chudzicka E, Pilipiuk L, Skibińska E, Sterzyńska M, Wytwer J (1994) Secondary succession of fauna in the pine forests of Puszcza Białowieska. Fragmenta Faun 37:3-104

Tsiafouli MA, Thébault E, Sgardelis SP, de Ruiter PC, van der Putten WH, Birkhofer K, Hemerik L, de Vries FT, Bardgett RD, Brady MD, Bjornlund L, Jørgensen HB, Christensen S, Hertefeldt TD, Hotes S, Hol WHG, Frouz J, Liiri M, Mortimer SR, Setälä H, Tzanopoulos J, Uteseny K, Pižl V, Starý J, Wolters V, Hedlund K (2015) Intensive agriculture reduces soil biodiversity across Europe. Glob Change Biol 21:973-985. https://doi.org/10.1111/ gcb. 12752

Twardowski JP, Hurej M, Gruss I (2016) Diversity and abundance of springtails (Hexapoda: Collembola) in soil under 90-year potato monoculture in relation to crop rotation. Arch Agron Soil Sci 62:1158-1168. https://doi.org/10.1080/03650340.2015.1131270

Tyurin IV (1931) A new modification of the volumetric method of determining soil organic matter by means of cromic acid. Pochvovedenie $26: 36-47$

Van Straalen NM (1998) Evaluation of bioindicator systems derived from soil arthropod communities. Appl Soil Ecol 9:429-437. https://doi.org/10.1016/S0929-1393(98)00101-2

Van Straalen NM, Verhoef HA (1997) The development of a bioindicator system for soil acidity based on arthropod $\mathrm{pH}$ preferences. J Appl Ecol 34:217-232. https://doi.org/10.2307/2404860

Vanbergen AJ, Watt AD, Mitchell R, Truscott AM, Palmer SCF, Ivits E, Eggleton P, Jones TH, Sousa JP (2007) Scale-specific correlations between habitat heterogeneity and soil fauna diversity along a landscape structure gradient. Oecologia 153:713-725. https:// doi.org/10.1007/s00442-007-0766-3

Vanhée B, Devigne C (2018) Differences in Collembola species assemblages (Arthropoda) between spoil tips and surrounding environments are dependent on vegetation development. Sci Rep 8:18067. https://doi.org/10.1038/s41598-018-36315-1

Varamesh S, Hosseini SM, Behjou FK, Fataei E (2014) The impact of land afforestation on carbon stocks surrounding Tehran. Iran J For Res 25:135-141. https://doi.org/10.1007/s11676-014-0438-1

Vesterdal L, Ritter E, Gundersen P (2002) Change in soil organic carbon following afforestation of former arable land. Forest Ecol Manag 169:137-147. https://doi.org/10.1016/S0378 $-1127(02) 00304-3$

Wachira P, Kimenju J, Okoth S, Kiarie J (2014) Conservation and sustainable management of soil biodiversity for agricultural productivity. In: Kaneko N, Yoshiura S, Kobayashi M (eds) Sustainable living with environmental risks. Springer, Tokyo, pp 27-34

Young J, Watt A, Nowicki P, Alard D, Clitherow J, Henle K, Johnson R, Laczko E, McCracken D, Matouch S, Niemela J, Richards C (2005) Towards sustainable land use: Identifying and managing the conflicts between human activities and biodiversity conservation in Europe. Biodivers Conserv 14:1641-1661. https://doi. org/10.1007/s10531-004-0536-z

Zeppelini D, Bellini BC, Creão-Duarte AJ, Hernández MIM (2009) Collembola as bioindicators of restoration in mined sand dunes of Northeastern Brazil. Biodivers Conserv 18:1161-1170. https ://doi.org/10.1007/s10531-008-9505-2 
Zhao J, Shao Y, Wang X, Neher DA, Xu G, Li Z, Fu S (2013) Sentinel soil invertebrate taxa as bioindicators for forest management practices. Ecol Ind 24:236-239. https://doi.org/10.1016/j.ecoli nd.2012.06.012
Publisher's Note Springer Nature remains neutral with regard to jurisdictional claims in published maps and institutional affiliations. 